\title{
Correction to: Population Cellular Kinetics of Lisocabtagene Maraleucel, an Autologous CD19-Directed Chimeric Antigen Receptor T-Cell Product, in Patients with Relapsed/Refractory Large B-Cell Lymphoma
}

\author{
Ken Ogasawara ${ }^{1}$ (D) $\cdot$ Michael Dodds ${ }^{2} \cdot$ Timothy Mack$^{1} \cdot$ James Lymp $^{3} \cdot$ Justine Dell'Aringa ${ }^{3} \cdot$ Jeff Smith $^{3}$
}

Published online: 3 July 2021

(c) The Author(s) 2021

\section{Correction to: Clinical Pharmacokinetics https://doi.org/10.1007/s40262-021-01039-5}

In this article, the affiliation details of Corresponding Author 'Ken Ogasawara' was incorrectly given as

Cellular Therapy \& Hematology, Clinical Pharmacology \& Pharmacometrics, Bristol Myers Squibb, Princeton, NJ, USA

It should have been

Bristol Myers Squibb, Princeton, NJ, USA
The original article has been corrected

Open Access This article is licensed under a Creative Commons Attribution-NonCommercial 4.0 International License, which permits any non-commercial use, sharing, adaptation, distribution and reproduction in any medium or format, as long as you give appropriate credit to the original author(s) and the source, provide a link to the Creative Com[1] mons licence, and indicate if changes were made. The images or other third party material in this article are included in the article's Creative Commons licence, unless indicated otherwise in a credit line to the material. If material is not included in the article's Creative Commons licence and your intended use is not permitted by statutory regulation or exceeds the permitted use, you will need to obtain permission directly from the copyright holder. To view a copy of this licence, visit http://creativecommons.org/licenses/by-nc/4.0/.
The original article can be found online at https://doi.org/10.1007/ s40262-021-01039-5.

\footnotetext{
Ken Ogasawara

ken.ogasawara@bms.com

Bristol Myers Squibb, Princeton, NJ, USA

2 Certara, Princeton, NJ, USA

3 Bristol Myers Squibb, Seattle, WA, USA
} 